\title{
Turkey's role in the global development assistance community: the case of TIKA (Turkish International Cooperation and Development Agency)
}

\author{
HAKAN FIDAN \& RAHMAN NURDUN
}

To cite this article: HAKAN FIDAN \& RAHMAN NURDUN (2008) Turkey's role in the global development assistance community: the case of TIKA (Turkish International Cooperation and Development Agency), Journal of Southern Europe and the Balkans, 10:1, 93-111, DOI: 10.1080/14613190801895888

To link to this article: https://doi.org/10.1080/14613190801895888

曲 Published online: 29 Feb 2008.

Submit your article to this journal 주

Џ Article views: 631

Citing articles: 13 View citing articles $[7$ 


\title{
Turkey's role in the global development assistance community: the case of TIKA (Turkish International Cooperation and Development Agency)
}

\author{
HAKAN FIDAN and RAHMAN NURDUN
}

\section{Introduction}

Although the world has never been wealthier than its current state, there are more than a billion people, one in five of the world's population, still living in extreme poverty. As the world has become 'a global village' in the last century, the problems of nations are not only their own problems but the problems of the international community. International crime, wars and conflicts, trade in illegal drugs, the spread of diseases like AIDS and thousands of refugees from troubled zones in and around developed and relatively better-off states, attest to that.

To tackle development problems globally, the United Nations developed its own institutions like the United Nations Development Programme (UNDP), International Trade Centre (ITC), etc. in the 1960s. However, these institutions have never been adequate to respond to the needs of underdeveloped and developing nations. As a result of this, national development cooperation agencies were established to help alleviate the burden of the UN institutions. As well as highly developed nations' agencies like the United States Agency for International Development (USAID), Deutsche Gesellschaft für Technische Zusammenarbeit (GTZ), Japan International Cooperation Agency (JICA), Canadian International Development Agency (CIDA), Department for International Development (DFID), etc., there emerged new donor countries to this equation in the recent decades as their economic situation began to allow them to help the outside world as well. Turkish International Cooperation and Development Agency (TIKA) is one example of this recent trend.

The emergence of new players in the donor community such as Turkey, India, Korea, Mexico, Russia and China has brought new impetus and opportunities to the global development community. Development assistance is also undergoing a serious transformation in the wake of 9/11; security and conflict resolution issues have become the main issues to be addressed by the top donors like the USA and Japan, although poverty reduction still occupies the central stage. Aid effectiveness, aid coordination and tied aid are becoming more and more focal points of the Development Assistance Committee (DAC) of OECD. In this context, Turkey represents a special case in the sense that on the one hand it is a recipient country, whereas on the other, it is also a donor country.

This paper attempts to analyse accomplishments as well as shortfalls of Turkey's Official Development Assistance (ODA). It starts with an overview of changing trends of development assistance and its future challenges, and then 


\section{Hakan Fidan and Rahman Nurdun}

continues with what Turkey has managed to do with its dual identity both as a donor and a recipient country. By describing Turkey's motives and main priority areas, the establishment of the Turkish International Cooperation and Development Agency (TIKA) and its undertakings are explored. To stress the importance of aid coordination, the issue of working with other aid agencies is discussed. We conclude by way of discussing ways in which Turkey can improve its donor status.

\section{The drive for giving aid}

Generally speaking, the objective of most of the foreign aid originated from the need to alleviate poverty and encourage progress in developing nations. As agreed by the world leaders at the United Nations Millennium Summit in September 2000, the Millennium Declaration calls for the international development community to come together around a common, global agenda to alleviate poverty. Millennium Development Goals (MDGs) devised after this call aim to get rid of extreme poverty and hunger (Goal 1), to make sure that all children receive primary education (Goal 2), to promote gender equality and give more power to women (Goal 3), to reduce child death rates (Goal 4), to improve the health of mothers (Goal 5), to combat HIV, AIDS, malaria and other diseases (Goal 6), to make sure that the environment is protected (Goal 7) and to develop a global partnership for development (Goal 8). British Prime Minister Tony Blair's report, published in March 2005, also echoes the MDGs with special reference to poverty reduction in Africa. ${ }^{1}$

To achieve the MDGs' programmes, developing countries are expected to put in place a proper environment through adoption and implementation of appropriate policies that will lead to economic growth, private sector investment and empowerment of the poor, while developed countries are charged with the responsibility of ensuring that their macroeconomic policies contribute to stability and growth in the world economy. Under the Monterrey Consensus ${ }^{2}$ it is also envisaged that increased support from developed countries will be forthcoming in the areas of trade policy and development aid. The international donor community was requested at Monterrey to provide the financing needed to achieve the MDGs. ${ }^{3}$

\footnotetext{
${ }^{1}$ For further details, see Report of the Commission for Africa, Our Common Interest, March 2005.

${ }^{2}$ The Monterrey Consensus was the outcome of the 2002 Monterrey Conference, the United Nations International Conference on Financing for Development. It was adopted by Heads of State and Government on 22 March 2002. Since its adoption the Monterrey Consensus has become the major reference point for international development cooperation. The document embraces six areas of Financing for Development: (1) mobilizing domestic financial resources for development; (2) mobilizing international resources for development: foreign direct investment and other private flows; (3) international trade as an engine for development; (4) increasing international financial and technical cooperation for development; (5) external debt; (6) addressing systemic issues: enhancing the coherence and consistency of the international monetary, financial and trading systems in support of development. More detailed information is available at: <http://en.wikipedia.org/wiki/ Monterrey_Consensus $>$.

${ }^{3}$ UN Millennium Development Goals, UN Internet site, < http://www.un.org/millenniumgoals/> .
} 
According to Japan's Official Development Assistance Charter, the purpose of providing ODA is to support the self-help efforts of developing countries towards economic take-off. While implementing ODA, donors are encouraged to ensure efficient and fair distribution of resources and 'good governance' in developing countries through developing a wide range of human resources and socio-economic infrastructure, including domestic systems, and through meeting the basic human needs, thereby promoting the sound economic development of the recipient countries. ${ }^{4}$ For DFID (Department for International Development of the UK Government), providing ODA can reduce poverty through the provision of more focused and coordinated development assistance by the international community to low and middle-income countries. ${ }^{5}$ The ODA purpose of Australia is to assist developing countries to reduce poverty through sustainable economic and social development. ${ }^{6}$

Aid has not always been given with humanitarian motives, but in some cases for a variety of political, strategic and economic reasons that benefit the donor countries in the long run. ${ }^{7}$ During the period of the cold war up to the 1980s much ODA went to least developed countries (LDCs) for the purpose of maintaining politically acceptable governments and the supply of natural resources that many LDCs produced. It is observed that the fear of LDCs becoming allies of the former Soviet Union motivated considerable foreign aid from the West. ${ }^{8}$ Likewise, the Soviet Union also provided development assistance to Eastern Bloc countries to maintain their allegiance.

To ensure that the savings gap and the foreign exchange gap are filled is another reason that forced donors to give ODA to LDCs. For domestic investment to take place domestic savings must also occur. If these are absent, then a flow of development assistance can help finance investment projects. Likewise, an inflow of foreign exchange may also enable LDCs to import foreign capital considered necessary for economic growth and development. ${ }^{9}$

The self-interest is another driving force for donor communities to deliver ODA to partner countries. As illustrated by Doss, less and less development assistance is delivered in the form of outright grants and interest is being charged although at concessionary rates. Tied aid occurs where conditions are imposed by the donor upon the partner countries how to use the aid assistance as in the case of Japan's ODA deliverance. ${ }^{10}$ Usually the recipients are required to purchase the exports of the donors. ${ }^{11}$ This may be a more expensive option than purchasing the capital from sources other than the donors. Tied aid may help fill savings and foreign exchange gaps; however, it may not always be in the best

\footnotetext{
${ }^{4} J a p a n ' s$ ODA, Annual Report 1999, <http://www.mofa.go.jp/policy/oda/summary/1999/ ref1.html> .

${ }^{5}$ Department for International Development, see < http://www.dfid.gov.uk/aboutdfid/> .

${ }^{6}<$ http://www.ausaid.gov.au/publications/pdf/simons/simons.pdf $>$.

${ }^{7}$ Masahiro Kawai and Shinji Takagi, 'Japan's official development assistance: recent issues and future directions', Journal of International Development, 16, 2004, pp. 259-261.

${ }^{8}<$ http://www.bized.ac.uk/virtual/dc/aid/theory/th6.htm > ; < http://are.berkeley.edu/ courses/EEP151/fall2004/handouts/Handout14-Aid.pdf $>$.

${ }^{9}$ Ibid.

${ }^{10}$ Veda Doss, 'Japan's development aid: self-interest or economic partnership', International Advances in Economic Research, 2(3), August 1996, pp. 232-243.

${ }^{11}$ Howard White and Simon Feeny, 'An examination of the long-run trends and recent developments in foreign aid', Journal of Economic Development, 28(1), June 2003, p. 130.
} 
96 Hakan Fidan and Rahman Nurdun

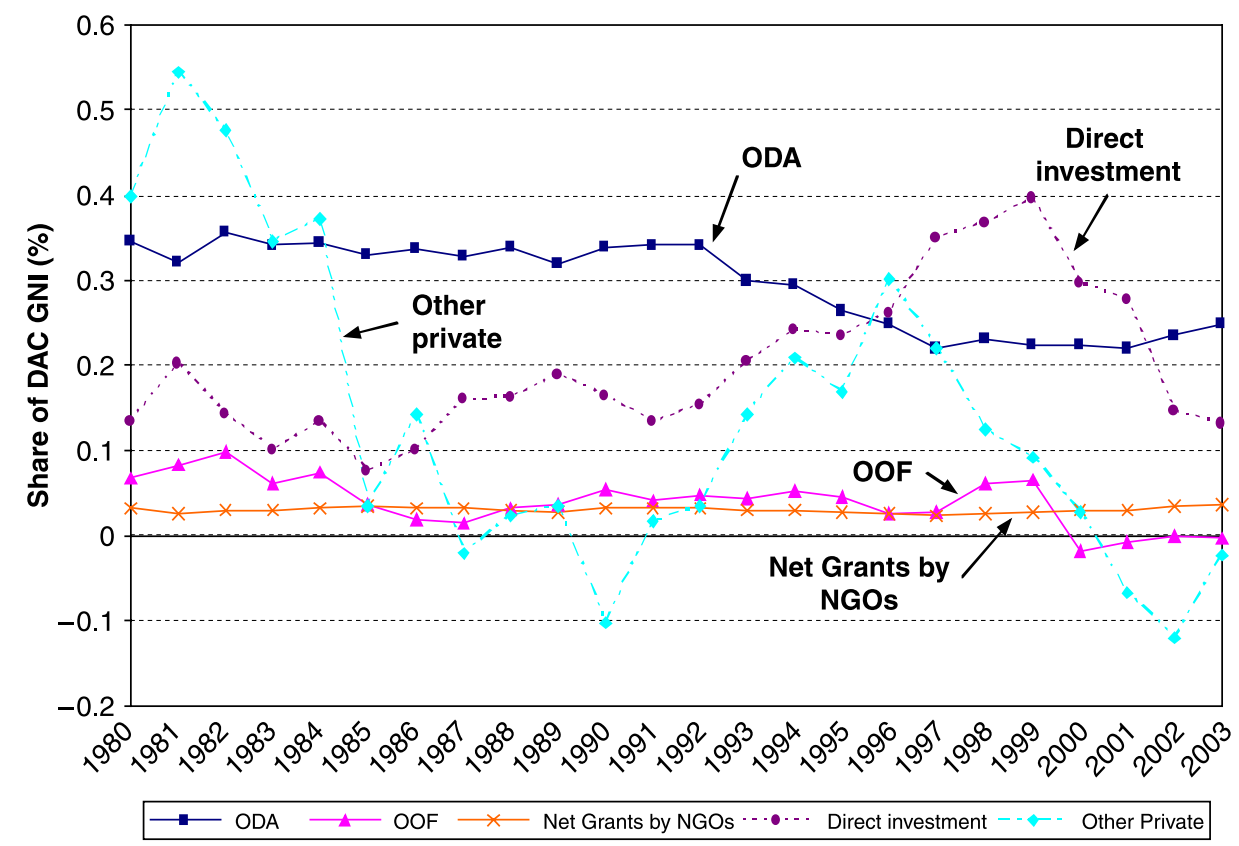

Figure 1. DAC member countries' resource flows to developing countries. Source: OECD DCD/DAC (2005) 11/ANN1, Mobilising Private Investment for Development: Policy Lessons on the Role of ODA, p. 5.

interests of the recipient country. ${ }^{12}$ While pursuing self-interest, bilateral donors tend to focus on geographical patterns and historical links. ${ }^{13}$ For instance, France and the UK provide aid to their former colonies, Japan concentrates on East Asia, Turkey sends aid to Eurasian countries.

\section{Changing international trends in development assistance}

It is widely known that the real value of foreign aid has fallen during the 1990s following two decades of relative stability, partly because of the diversion of aid flows to transition economies and unstable regions ${ }^{14}$ as shown in Figure 1 prepared by OECD/DAC. ${ }^{15}$ According to a report of the United Nations

\footnotetext{
${ }^{12}$ Ibid.

${ }^{13}$ See Tim Harford, Bita Hadjimichael and Michael Klein, 'Aid agency competition', Public Policy for the Private Sector, Note No. 277, October 2004, World Bank Group, pp. 2-3.

${ }^{14}$ Howard White and Simon Feeny, 'An examination of the long-run trends and recent developments in foreign aid', Journal of Economic Development, 28(1), June 2003, pp. 113-114; Finn Tarp and Peter Hjertholm, Foreign Aid and Development: Lessons Learnt and Directions for the Future, Routledge, London and New York, 2000, p. 4. According to a study of the Word Bank Group, ODA has fallen from 80 per cent of official flows in the 1970s to less than 60 per cent in the late 1990s. See Tim Harford, Bita Hadjimichael and Michael Klein, 'The supply of aid', Public Policy for the Private Sector, Note No. 276, October 2004, World Bank Group, pp. 2-3.

${ }^{15}$ Figure 1 presents trends in external resource flows to developing countries from the Development Assistance Committee's (DAC's) 22 member countries between 1980 and 2003, expressed as a share of DAC members' total gross national income (GNI).
} 
Table 1. Net private capital flows to developing and transition countries ${ }^{a}$ (current $\$$ billion)

\begin{tabular}{lcccr}
\hline & $1991-1993$ & $1994-1996$ & $1997-1999$ & $2000-2002$ \\
\hline FDI & 179 & 377 & 625 & 630 \\
Other private flows & 39 & 153 & 112 & -30 \\
\hline
\end{tabular}

${ }^{a}$ OECD DCD/DAC (2005) 11/ANN1, Mobilising Private Investment for Development: Policy Lessons on the Role of ODA, p. 10.

Economic Commission for Africa, budget constraints and the perception that ODA was not the catalyst for partner countries' economic development are among other reasons that obliged donors to reduce their ODA volume. ${ }^{16}$ Meanwhile, decreases in aid amounts have been followed by improvements in the quality of aid. The financial terms of aid have improved and there has been a move towards the untying of aid. ${ }^{17}$ Aid per capita rose from 1970 to 1990, but has fallen since. Foreign aid as sources of capital for LDCs has been largely displaced by FDI/FPI (foreign direct investment/foreign portfolio investment) ${ }^{18}$ as shown in Table 1.

Trends in ODA over the last few years have increased the emphasis on country ownership, growing reliance on partnerships and coordination, and progress towards internationally agreed development targets, such as MDGs,)clear national poverty reduction strategy (Poverty Reduction Strategy Program). It was argued in a meeting held in London in January 2004 that the following trends affected aid architecture: ${ }^{19}$

- Middle-income countries that no longer depend on aid, consider foreign aid as an intrusion into their national sovereignty.

- Multiple objectives of donors make aid complicated with other objectives, and stability and security concerns have become fuddled with poverty reduction.

- NGOs' pressure to get more official aid changed the system, because official aid is based on budget support, therefore, it is easier for NGOs to show the tangible benefits of their work and compete for funding.

It may be true that some middle-income countries do not want foreign aid simply because they believe that their national sovereignty is eroded. However, they should be encouraged to receive ODA before they reach the level of 'graduation' from ODA recipient status. Exclusion of such countries from ODA is against the general principles of equality.

It is true that big donors have multiple objectives that are entangled with other objects sometimes due to stability and security concerns, which dilute efforts at 'poverty reduction'. Poverty alleviation is not only the major goal

\footnotetext{
${ }^{16}$ United Nations Economic Commission for Africa, Capital Flows and Current Account Sustainability in Africa, ESPD/NRP/05/05, December 2005, p. 8, available at: <http://uneca.org/espd > .

${ }^{17}$ Howard White and Simon Feeny, 'An examination of the long-run trends and recent developments in foreign aid', Journal of Economic Development, 28(1), June 2003, pp. 113-114.

${ }^{18}<$ http://are.berkeley.edu/courses/EEP151/fall2004/handouts/Handout14-Aid.pdf $>$.

${ }^{19}<$ http://www.odi.org.uk/speeches/future_of_aid/meeting_report_14january04.html $>$.
} 


\section{Hakan Fidan and Rahman Nurdun}

of bilateral aid agencies, it also remains a major concern of the DAC/OECD agenda in recent years. ${ }^{20}$

NGOs' comparative flexibility and low profile in aid delivery make them well received in partner countries. They usually have easy access to various fields which are sometimes not open to ODA agencies; therefore, it is quite understandable that sometimes they are in a more favourable position to compete for aid allocation from governments.

Increasing effectiveness of ODA and development assistance agencies: future challenges

The Paris Declaration on Aid Effectiveness which was the result of an arduous High Level Forum on 28 February-2 March 2005 in Paris stressed the aid community's determination to continue with the agenda on ownership, harmonization, alignment and managing for development results. ${ }^{21}$ This declaration once again underscores the urgent need for the donor community to commit itself to improving aid effectiveness so as to support partner countries' efforts, while strengthening governance and improving development performance.

Despite various challenges encountered by the developing countries, remarkable progress has been achieved in the developing world over the past 50 years, in terms of growth, poverty reduction and human development. This progress has been spurred by improvements in developing country policies and institutions, by the integration of those economies into world markets and by supportive development assistance. Meanwhile, many countries and groups have not had their fair share of global growth; their lack of progress is attributable not only to poor policies and institutions in some countries, but also to a lack of market access and the mistakes in the design and delivery of development assistance. The Monterrey Consensus states that improving development progress of the past, partnerships among developed and developing countries and a framework of mutual accountability are essential. ${ }^{22}$ As Burnside and Dollar put it regarding aid effectiveness, aid works when there is a good policy environment. ${ }^{23}$ Thus, developing country policies, institutions and governance remain the key challenges facing the developing countries.

\section{Turkey as an ODA recipient and a donor country}

Turkey has been an aid recipient country since the late 1940s. With the implementation of the Marshall Plan, Turkey was offered ODA alongside Greece, inspired by the foreign policy concerns of the USA to support the pro-Western

\footnotetext{
${ }^{20}$ See OECD, Promoting Pro-Poor Growth: Key Policy Messages, 2006, available at: <http://www. oecd.org/dataoecd/33/54/36570936.pdf $>$.

${ }^{21}<$ http://www.aidharmonization.org $>$.

$22<$ http://wwwInweb18.worldbank.org $>$.

${ }^{23}$ Nancy Birdsall, Stijin Claessens and Ishac Diwan, 'Policy selectivity forgone: debt and donor behavior in Africa', World Bank Economic Review, 17(3), 2003, p. 409. According to a study of the World Bank Group, 'good policy environment' means a particular combination of low inflation, fiscal rectitude and an open economy, see Tim Harford and Michael Klein, 'Donor performance', Public Policy for the Private Sector, Note No. 278, October 2004, World Bank Group, p. 2.
} 
regimes established in Europe after the Second World War. Turkey received \$150 million of aid within the context of the Marshall Plan, which contributed a great deal to the economic development of Turkey in the 1950s. ${ }^{24}$ According to the figures provided by the US State Department, for the purpose of furthering Turkish economic development, the USA has loaned and granted Turkey more than $\$ 12.5$ billion in economic aid as of December 2005. ${ }^{25}$

In addition to the USA, Japan and Germany are the other two major donors for the betterment of Turkey's economic performance. Technical cooperation between Japan and Turkey started 45 years ago under the programme of 'Acceptance of Trainees'. Through JICA, Japan completed its 'development study' for Turkey in 1965, and its first project-type technical cooperation with Turkey was implemented between 1973 and 1979. Despite that interest, JICA's Turkey Office was only established in Ankara in June 1995. As of 2000, the total budget allocation for technical cooperation for Turkey amounted to roughly 31.46 billion Japanese yen (approximately $\$ 286$ million). ${ }^{26}$

Germany started its technical cooperation with Turkey through the Deutsche Gesellschaft für Technische Zusammenarbeit (GTZ) in 1970 within the framework of German-Turkish Technical Cooperation. On behalf of the German Federal Ministry for Economic Cooperation and Development (BMZ), GTZ provided assistance to a wide range of projects in different sectors of the Turkish economy during the 1970s and 1980s. As of 2003, Germany had delivered €271 million worth of technical assistance to Turkey in the last 33 years. ${ }^{27}$

In addition to the bilateral donors listed above, multilateral donors have also contributed to Turkey's development, notably the UNDP, with whom Turkey has enjoyed a positive cooperation relationship for the past 30 years. Over the years, the UNDP has brought in new ideas and agendas, promoted institutional capacity and succeeded in getting significant and enduring human development results in various areas by using its resources flexibly on a sustained basis. ${ }^{28}$ As of 2000, the UNDP's technical assistance rendered to Turkey had amounted to $\$ 33.12$ million. $^{29}$

Although Turkey is still on the DAC list as an aid recipient country, it started its aid activities on 5 June 1985 when it prepared a comprehensive aid package worth $\$ 10$ million to the Sahel countries ${ }^{30}$ under the coordination of Undersecretariat of State Planning Organization of Turkey (SPO). ${ }^{31}$ As of 1996, Turkey has contributed to the institutional capacity of Gambia, Guinea, Guinea Bissau, Mauritania, Senegal, Somali and Sudan. ${ }^{32}$ However, substantial aid to partner countries got an impetus when TIKA came into being in 1992. Although TIKA was initially established for the purpose of helping transition economies

\footnotetext{
${ }^{24}<$ http://marshallfoundation.org $>$.

${ }^{25}<$ http://www.state.gov/r/pa/ei/bgn/3432.htm $>$.

${ }^{26} \mathrm{JICA}$ Turkey Office.

${ }^{27}$ GTZ Turkey Office.

${ }^{28}$ VIII. BYKP-2005 Yilı Programı, < http://ekutup.dpt.gov.tr/program/2005/abil44.html> .

${ }^{29}$ Ibid.

${ }^{30}$ Sahel countries include Ethiopia, Sudan, Somalia, Mali, Niger and Chad.

${ }^{31}$ To enhance the technical cooperation between and by the private sectors, State Planning Organization published a catalogue under the title of 'Turkey's Technical Cooperation Capacities and Technology Transfer Potentials' in 1995.

${ }^{32}$ Nuri Birtek, Türkiye'nin Dış Yardımları ve Yönetimi, unpublished expert thesis, State Planning Organization of Turkey, September 1996, p. 37.
} 
100 Hakan Fidan and Rahman Nurdun

\begin{tabular}{|c|c|c|c|}
\hline Chart 2 & \multicolumn{3}{|c|}{$\begin{array}{l}\text { TOP COUNTRES BENEFITTED FROM TURISH ODA } \\
\qquad \text { Table-2 }\end{array}$} \\
\hline $\begin{array}{l}\text { I. CATEGORY } \\
\text { COUNTRIES }\end{array}$ & Milion USD & $\begin{array}{l}\text { I. CATEGORY } \\
\text { COUNTRIES }\end{array}$ & Million USD \\
\hline EUROPE & 30,19 & GEORG|A & 4,60 \\
\hline$A \perp B$ BANA & 4,71 & KAZAKHSTAN & 27,17 \\
\hline BOSNNA-AERREG & 5,79 & KYRGYZSTAN & 34,74 \\
\hline MACEDIONIA & 4,09 & TAIIKISTAN & 6,48 \\
\hline Kosin/A. & 12,65 & TURKMENISTAN & 18,82 \\
\hline ASIA & 195,46 & UZEEKSTAN & 5,48 \\
\hline IFAN & 12.23 & MONGOUA & 5,47 \\
\hline $\mathrm{IRAQ}$ & 24,57 & & \\
\hline FA.LESTINE & 4,49 & $\begin{array}{l}\text { II. CATEGORY } \\
\text { COUNTRIES }\end{array}$ & Milion USD \\
\hline EA,UDI ARABEIA, & 9,73 & NORTH CYPRUS. & 9,24 \\
\hline AFGHANISTAN & 8,74 & BULGAREA & 11,19 \\
\hline$A Z E R B, A I, J A N$ & 22,90 & RUSSIA & 10,38 \\
\hline & & UKRANE & 6,10 \\
\hline
\end{tabular}

Figure 2. Top countries benefiting from Turkish ODA. Report for 2004.

in Central Asia, Caucasus and the Balkans, from 2003 onwards, TIKA began to reach out to the Middle East and North Africa (MENA) countries and African countries.

According to the figures released by the Turkish Statistical Institute (TURKSTAT) and State Planning Organization of Turkey at the end of 2003, official flows from Turkey have amounted to $\$ 3.8$ billion $^{33}$ of which TIKA has constituted a $\$ 98$ million portion of technical assistance to partner countries, among which 47 per cent of TIKA's aid went to Kazakhstan, 13 per cent to Azerbaijan, 9.4 per cent to Turkmenistan, 8.6 per cent to Crimea (Ukraine) and 22 per cent to others. ${ }^{34}$

The ODA figure for 2004 rose to $\$ 339.15$ million when TIKA took over the task of collecting Turkish ODA statistics from the State Statistics Institute in April 2005 and made a systematic calculation in accordance with OECD DAC Guidelines. Out of \$339.15 million, \$291.84 million worth of ODA went to Category I countries in the form of bilateral aid; $\$ 47.31$ million in terms of multilateral aid. In addition, $\$ 102.52$ million worth of OA (Official Aid) was made to Category II countries. ${ }^{35}$

As shown in Figure 2, among the Category I countries, Kyrgyzstan, Kazakhstan and Iraq are the top three beneficiaries of Turkish ODA, while Bulgaria and Russian Federation are the two top countries within Category II that enjoy Turkish ODA.

\footnotetext{
${ }^{33}$ Türkiye'nin İkili Dış Yardımları (1992-1996), D1ş Ekonomik İlişkiler Genel Müdürlüğü, DPT, Mart 1998; Haber Bülteni, 21 March 2000-29 April 2004, T. C. Başbakanlık Devlet İstatistik Enstitüsü.

${ }^{34}$ Report of Strategy Development and Planning Team of TIKA.

${ }^{35}$ According to OECD DAC Guidelines, aid delivered to Categorey II countries are not counted as ODA.
} 


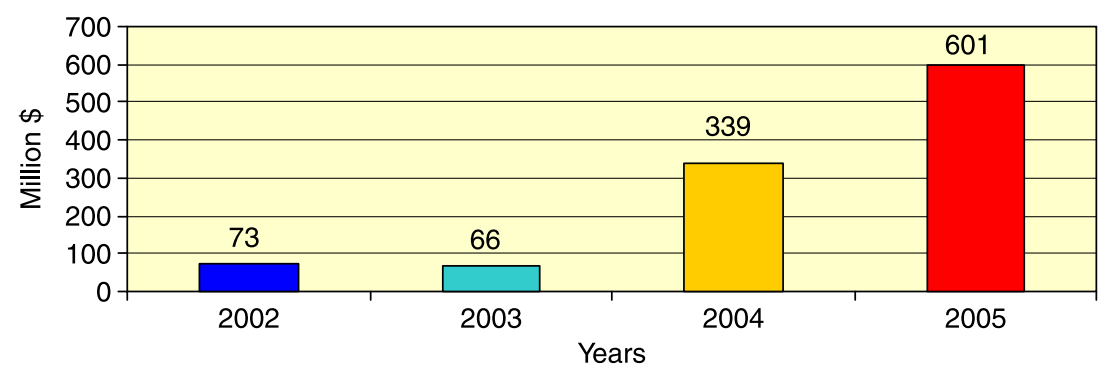

Figure 3. Turkish ODA in 2002-2005 (\$ million).

When the regional breakdown of Turkish ODA is examined as in Figure 2, Asia is at the top of the list with $\$ 195.46$ million; Europe is in second place with \$30.19 million, and with \$29.10 million, Central and Eastern Europe with former Soviet Union countries rank third.

It is indicated from Figure 3 that there is a sharp increase in ODA from 2004 to 2005. This huge increase can be attributed to the following three reasons: (i) the adequate reporting of Turkish humanitarian aid to Pakistan after the earthquake and the Tsunami disaster in South-east Asia; (ii) Turkey's recent aid projection to Africa and the Middle East; and (iii) getting access to other governmental actors' ODA figures.

As shown in Figure 4, it appears that Pakistan was the top recipient in 2005 due to the emergency assistance it received in the aftermath of the earthquake. Educational activities within the context of ODA played a decisive role in the formation of such ranking. When the regional breakdown of Turkish ODA for 2005 is examined as in Figure 4, the Asian region was at the top of the list with $\$ 442.49$ million including the Far East, and the European region (Balkans and Eastern Europe) was in second place with $\$ 96.59$ million.

Figure 5 indicates that Pakistan, Kyrgyzstan, Kazakhstan, Azerbaijan and Afghanistan, which are ODA recipients according to the DAC criteria, occupy the top five ranks, followed by Indonesia, Bosnia-Herzegovina and Kosovo.

As it is clearly shown in Figure 6, Caucasus and Central Asian countries remain the main destinations of Turkish ODA in comparison with the other regions.

\section{Turkey's motives for the ODA and main destinations}

Although Turkey has been and still is an ODA recipient, it initiated a technical assistance programme towards other developing countries, especially toward the LDCs during the mid-1980s. Security concerns and economic interest can be considered as the main motives of Turkish aid.

The dramatic changes that occurred in Europe in the late 1980s and early 1990s, brought about the collapse of the Warsaw Pact, the dissolution of the former Soviet Union, the emergence of new independent states, among which

\footnotetext{
${ }^{36}$ Orhan Güvenen, 'Turkey's medium and long-term strategic objectives: TR 2007/15-TR 2017/9', Perceptions (Journal of International Affairs), IV(4), December 1999-February 2000, p. 8.
} 
102 Hakan Fidan and Rahman Nurdun

\begin{tabular}{|l|r|l|r|}
\hline EUROPE TOTAL & 96.59 & FAR EAST & 46.01 \\
\hline BOSNIA-HERZEGOVINA & 18.62 & INDONESIA & 26.53 \\
\hline KOSOVO & 16.23 & MONGOLIA & 10.32 \\
\hline UKRAINE & 9.92 & $\begin{array}{l}\text { OTHER FAR } \\
\text { EAST } \\
\text { COUNTRIES }\end{array}$ & 9.16 \\
\hline ALBANIA & 6.98 & & \\
\hline MACEDONIA & 6.57 & & 59.49 \\
\hline MOLDOVA & 5.40 & & 11.92 \\
\hline $\begin{array}{l}\text { OTHER EUROPEAN } \\
\text { COUNTRIES TOTAL }\end{array}$ & 32.87 & & 10.37 \\
\hline ASIA TOTAL & 422.49 & OTHER & \\
\hline MIDDLE EAST TOTAL & 43.99 & CATEGORY \\
COUNTRIES & \\
\hline IRAQ & 12.92 & NORTHERN \\
CYPRUS & \\
\hline PALESTINE & 11.16 & BULGARIA & \\
\hline SAUDI ARABIA & 10.30 & RUSSIAN & \\
\hline $\begin{array}{l}\text { OTHER MIDDLE EAST } \\
\text { COUNTRIES TOTAL }\end{array}$ & 9.61 & & \\
\hline SOUTH AND CENTRAL ASIA & 332.49 & & \\
\hline PAKISTAN & 126.17 & & \\
\hline KYRGYZSTAN & 47.45 & & \\
\hline KAZAKHSTAN & 36.40 & & \\
\hline AFGHANISTAN & 28.56 & & \\
\hline AZERBAIJAN & 28.62 & & \\
\hline TURKMENISTAN & 50.32 & & \\
\hline $\begin{array}{l}\text { OTHER ASIAN COUNTRIES } \\
\text { TOTAL }\end{array}$ & & & \\
\hline
\end{tabular}

Figure 4. Countries receiving most development assistance (\$ million). Report year: 2005.

Azerbaijan, Uzbekistan, Turkmenistan, Kazakhstan and Kyrgyzstan are of Turkic origin. Cultural ties with the Turkish speaking Central Asian countries plus Azerbaijan and some Balkan countries enabled Turkish foreign aid to gain momentum, reaching 0.17 per cent of its gross national income (GNI) for the first time in recent memory.

These changes had a profound political, economic and cultural significance for Turkey, because in the post-cold war period, Turkey found herself at the centre of a large area stretching from the Adriatic Sea to Central Asia, which is destined to gain increasing geopolitical importance in the 21st century. ${ }^{36}$ Turkey, with its experience in democracy and market economy, and its cultural, economic and ethnic ties with the vast majority of the countries in the area, has felt the need to contribute to the transformation efforts of the Eurasian countries. Turkey's initiative was also demand-driven as these countries more and more expected Turkey to meet their needs considerably.

\footnotetext{
${ }^{37}$ For a detailed definition for 'technical assistance', see Heather Baser, 'Technical assistance and institutional development', presentation to DAC/TIKA Workshop on Principles for Effective External Assistance to the New Eurasian States, Canadian International Development Agency (CIDA), 17 January 1994; Elliot J. Berg, Rethinking Technical Cooperation-Reforms for Capacity Building in Africa, 1993, United Nations Development Programme, New York, 1993, pp. 44-46.
} 


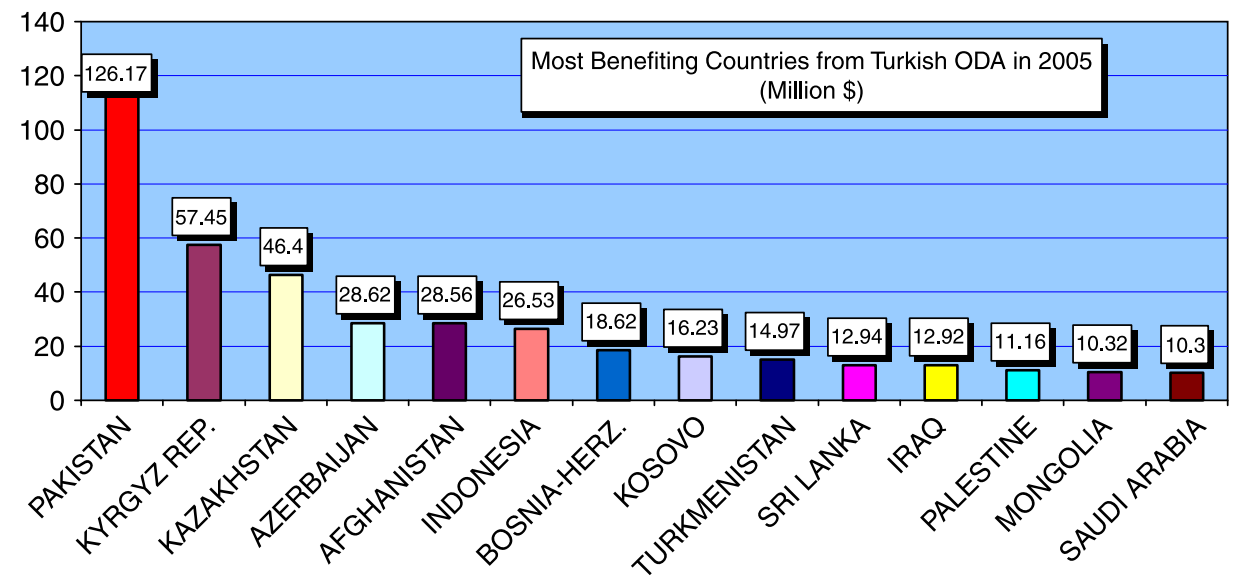

Figure 5. Countries benefiting the most from Turkish ODA in 2005 (\$ million).

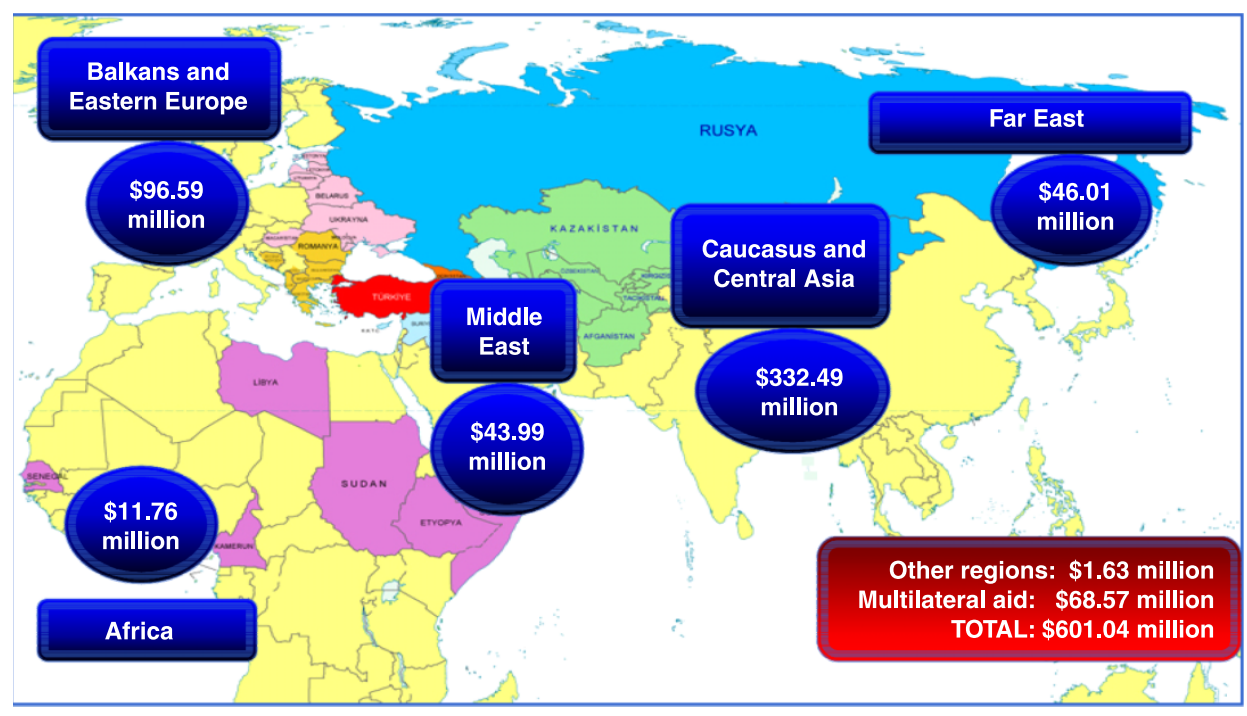

Figure 6. Regions receiving the most Turkish ODA in 2005.

In this regard, to coordinate Turkey's increasing ODA, TIKA was established under the Foreign Ministry of Turkey in 1992 for the purpose of helping newly independent states in Central Asia, Caucasus, Black Sea and the Balkans. Thus, Turkey became the first country that went into action to give technical assistance to Eurasian countries. ${ }^{37}$

TIKA was attached to the Prime Ministry in 1999 to increase its efficiency. Ever since then, TIKA has evolved into the principal Turkish official development cooperation agency with field offices in Albania, Azerbaijan, Bosnia and

\footnotetext{
${ }^{38}$ For detailed elaboration on capacity development, see Carlos Lopes and Thomas Theisohn, Onwership, Leadership and Transformation: Can We Do Better for Capacity Development?, UNDP, Earthscan, 2003, pp. 22-28.
} 


\section{Hakan Fidan and Rahman Nurdun}

Herzegovina, Georgia, Kazakhstan, Kyrgyzstan, Macedonia, Moldova, Mongolia, Palestinian Authority, Sudan, Tajikistan, Turkmenistan, Ukraine, Uzbekistan, Kosovo, Ethiopia and Afghanistan to facilitate its overseas operations. Out of 170 employees, some 36 are working at the field offices with 89 local support staff. In the countries where TIKA does not have a field office, the projects are carried out through Turkish embassies. Although TIKA's activities are still concentrated in Central Asia, Caucasus, Black Sea region and the Balkans, it is reaching out to the Middle East and Africa to address the issue of sustainable development of an even wider world.

TIKA's activities in the last 12 years (1994-2006) have been mainly concentrated on institutional development/capacity building ${ }^{38}$ in the areas of banking and central banking, tax training, improvement of the private sector, tourism, customs, diplomacy, public governance, insurance, statistics, agriculture, development of small and medium-sized enterprises (SMEs) as well as social cooperation in the Eurasian countries. ${ }^{39}$ TIKA's capacity-building activities undertaken on a regional basis in recent years have been quite successful. ${ }^{40}$ The most important is OECD-TIKA Istanbul Private Sector Development Centre. The Centre's original mission was to train government officials from transition economies in Eastern Europe, Central Asia and Transcaucasus. Courses dealt mainly with the privatization and restructuring of state-owned enterprises; the role and structure of public sector enterprises; competition policy and demonopolization; foreign investment; banking and insurance; accounting; development of SMEs; and legal reforms. ${ }^{41}$

TIKA makes a $\$ 200,000$ voluntary contribution annually to the OECD core budget for the continuation of the activities in the Centre. Within the context of the project, TIKA's total contribution has amounted to $\$ 3,366,000$. Over the years, the training centre evolved into a regional OECD centre, providing a forum for policy dialogue and regional cooperation on key OECD issues of interest to transition economies. Since its opening, the Centre has organized 156 meetings with 3090 high-level participants from the Eurasian countries.

The OECD Istanbul Centre has adjusted itself to the changing environment in the partner countries. It has created a unique opportunity in bringing together representatives from OECD member countries, including more advanced Eastern European countries, and less developed transition economies to benefit mutually from each other's experiences. Indeed, it is in a unique position to facilitate this exchange of knowledge and experience. TIKA's vision for the Centre is to transform it into a fully fledged OECD Centre in the future.

\footnotetext{
${ }^{39}$ Öner Kabasakal, 'Türk Cumhuriyetlerinin Ekonomik Kalkınmalarında TİKA'nın Rolü', Dış Ticaret Dergisi, Special Issue, January 2002, pp. 12-18.

${ }^{40}<$ http://www.tika.gov.tr $>$.

${ }^{41}$ Annual Report of the OECD Istanbul Private Sector Development Centre prepared by the Executive Board.

${ }^{42}$ This expression means the project has a volume of offering 1442 men one-day consulting services.

${ }^{43}$ TIKA 2004 Yil Faaliyet Raporu, < http://www.tika.gov.tr> .

${ }^{44}$ Turcology Project refers to sending Turkish teachers to partner countries which have a shortage of Turkish language teaching as well as materials.

${ }^{45}$ TIKA 2004 Yil Faaliyet Raporu, <http://www.tika.gov.tr>.
} 
The Project for Strengthening Statistics is another example of institutional development. This project has been continuing since 1994 in cooperation with TURKSTAT. The target countries are Azerbaijan, Bosnia-Herzegovina, Georgia, Kazakhstan, Kyrgyzstan, Macedonia, Mongolia, Uzbekistan and Turkmenistan. As of 2006, 1442 man-days ${ }^{42}$ of consulting services had been offered to the region and 1637 man-days on-the-job training had been realized. ${ }^{43}$

In response to the request of some countries in the region, the Turcology Project $^{44}$ was started in 2000. TIKA supports Turkish language teaching and education with this project. It was undertaken in cooperation with 14 countries and two autonomous republics in 2005-2006. In the partner universities, 24 Turkish scholars, 14 local scholars and a number of support staff are employed. Within the context of the Turcology Project, libraries and Turkish Language and Culture Centres were established. ${ }^{45}$ Although this project might seem a cultural project, it has in fact economic benefits as well. Many people who have taken part in these educational programmes increased their chances of finding better paid jobs in a region where unemployment is endemic. Many graduates work with Turkish companies investing in the regions.

Although due to the nature of the above-mentioned projects, one may conclude that these are donor-driven projects, it should also be noted that TIKA has achieved a great deal of success with them with its modest budget and contributed positively to the well-being of people in the newly independent states since its establishment in 1992. For instance, some partner countries have taken significant steps on the path to democratization and have developed their systems of government, while some have begun to play active roles in international politics. In the newly independent countries, communications systems have been established; transportation links with foreign countries have been developed with airlines in the lead; banks have been established; the required legislative changes have been made for transition to a free market economy, privatization and the encouragement of foreign investment and small enterprises; trade with foreign countries has developed and significant investments have been realized.

TIKA and other Turkish organizations provided very important contributions for these developments. While performing its technical cooperation activities, TIKA cooperates with the public and private sectors in Turkey, as well as international and bilateral development agencies.

Of course, these accomplishments were not achieved easily, as there had been some initial difficulty in delivering aid to the region. Just like Berg pointed out by quoting Pierre-Claver Damiba, at the beginning, some countries perceived technical cooperation, at best, as a free good and, at worst, as something imposed by the donors. ${ }^{46}$ Because the donors who control the process normally allocate resources through budgeting and programming, therefore, technical cooperation is programmed by donors, and not by recipients. ${ }^{47}$ To avoid these misunderstandings, TIKA has been conducting its technical assistance by responding to the requests of partner countries.

\footnotetext{
${ }^{46}$ See, Elliot J. Berg, Rethinking Technical Cooperation-Reforms for Capacity Building in Africa, 1993, United Nations Development Programme, New York, 1993, foreword.

${ }^{47}$ Ibid.

${ }^{48}$ Ibid.
} 
It is widely accepted by the donor community that virtually all partner countries believe that technical cooperation is out of sync with availability of trained local human resources. ${ }^{48}$ Thus, while implementing projects, TIKA tries its best to take advantage of local experts, as was the case with the Turkish Monuments Project in Mongolia, the restoration project of Hoca Ahmet Yesevi Mausoleum in Kazakhstan, and the Crimean Tatar Housing Project in Ukraine. Some country-specific projects in Georgia, Afghanistan, Palestine and Ethiopia confirm that TIKA's main destinations of ODA also include Middle Eastern countries apart from the Eurasian nations.

Since 1992, TIKA has been developing projects in various fields in Georgia. In order to ensure the coordination of different projects and provide advisory services TIKA opened its Program Coordination Office in Tbilisi in early 1995. During the period 1992-2005, TIKA has implemented 47 country projects for Georgia. For instance, an industrial feasibility study, school restoration, provision of education materials, publication of various catalogues and reviews, provision of drinking water and statistics, etc. The total amounts of implemented projects for Georgia by 2005 were $\$ 5,868,000$.

TIKA declared the allocation of a sum of $\$ 5$ million on behalf of Turkey for Georgia at the 'Donors Conference' in Brussels in 2004 in a five-year period between 2004 and 2008. Within this context, TIKA spent \$537,000 in 2004 and $\$ 800,000$ in 2005 for the bilateral projects in Georgia. Those projects include 'fighting the IPS Typographus insect in the Adjara' which strengthened the capacities of the staff of the Forest Ministry of Adjara to combat the harmful effects of the IPS Typographus insect. The USA was the biggest donor at this Conference, pledging $\$ 360$ million of which $\$ 53$ million was to be used for 'security assistance', while the EU Commission pledged a sum of $\$ 151.6$ million, of which some portion was allocated for rehabilitation measures in conflict regions of Abkhazia and South Ossetia. ${ }^{49}$ Individual EU member countries also declared their additional shares, among which Germany pledged \$31.4 million, the UK \$27.4 million, Sweden \$21.5 million, the Netherlands \$21.2 million, Finland \$1.6 million and Belgium \$1.2 million. Non-EU member Switzerland offered $\$ 15.4$ million and Japan pledged $\$ 3.8$ million. ${ }^{50}$

At first glance, Turkey's pledge is of little significance in comparison with that of the USA and the EU, but when compared with that of better-off EU countries like Finland and Belgium, Turkey's contribution is of considerable value given the fact Turkey is not a rich country itself. To support another initiative of the OSCE (Organization for Security and Co-operation in Europe) which kicked off on 14 June 2006 for the promotion of 'Economic Rehabilitation in the Zone of Georgian-Ossetian Conflict', Turkey made its offer of $\$ 95,000$ to support the project 'Construction of a Water Pipeline Ksuisi-Disevi-Gugutiankari', while the UK and Estonia agreed to pledge $€ 172,171.33$ and $€ 50$, respectively, to be used for other projects under the same initiative. ${ }^{51}$

\footnotetext{
${ }^{49}$ Ahto Lobjakas, 'Georgia: donors conference wins $\$ 1$ billion in pledges', < http://www.rferl.org/ featuresarticle/2004/06/eb7a45a1-d269-4f10-b4c5-22bedac732e2.html?napage $=1>$.

${ }^{50}<$ http://www.seerecon.org/georgia $>$.

${ }^{51}$ Official letters of the OSCE to the governments of the UK and Estonia, dated 19 September and 10 November 2006.
} 
To contribute to the post-conflict reconstruction of Afghanistan, on behalf of the Turkish Government, TIKA has been actively involved in the ODA activities since 2004. TIKA has made remarkable efforts to meet the challenges in the fields of education, health and water supply. Based on the bilateral protocols between the two governments, TIKA has started the construction of six elementary schools, one school of art and profession for woman and one high school for the relevant provinces located in the north of Afghanistan. At the end of 2005, 80 per cent of the construction had been completed. When the project is completed, 10,000 students will have a chance to receive education in a decent place. As health is among the overarching problems faced by the Afghan people, TIKA responded to the request of the Afghan Government to set up three hospitals with a capacity of housing 625 patients; two clinics with a capacity of serving 225 patients and two mobile hospitals in 2004 and they were all completed by the end of 2005. To address the need for fresh water supply, the digging of nine artesian wells was completed in 2005.

TIKA also set up a programme coordination office in Palestine in October 2004 to deliver aid to the Palestinian people. The successful withdrawal of Israeli troops from the Gaza Strip ushered in new hope for the economic development of the Gaza region. The Gaza/Erez Industrial Zone, which was severely hit by the Intifada and the disproportionate refugees of the Israeli Defence Forces, was offered a chance of regaining its vitality. The Zone in the past used to be the home for 200 firms with 4700 employees; therefore, its role in Gaza's economy cannot be neglected. In the light of this, Turkish Foreign Ministry, TIKA and Turkish Union of Chambers and Commodity Exchanges took the lead to revitalize the Zone.

\section{Cooperation with ODA agencies}

Following the enactment of the new TIKA law on 2 May 2001, 52 TIKA became an aid agency officially placed under the Prime Ministry and mandated to coordinate Turkey's foreign aid to developing countries, especially to the countries or regions where Turkic languages are spoken. Until that time alongside with TIKA, various Turkish public institutions such as State Planning Organization, Treasury and Foreign Trade Under-secretariat had responded to the needs of the Eurasian countries in their fields of specialization by accomplishing 1180 assistance activities and 1505 cooperation activities between

\footnotetext{
${ }^{52}<$ http://www.byegm.gov.tr/YAYINLARIMIZ/AyinTarihi/2001/mayis2001.htm> .

${ }^{53}$ Mustafa Yilmaz, 'An assessment of Turkey's activities towards the Turkish world', Eurasian Studies, Issue 22, Spring 2002, pp. 165-192.

${ }^{54}$ For success stories of USAID and its budget for Central Asian countries see $<$ http://www.usaid. gov / locations/europe_eurasia/car/successarchive/index.html > ; for achievements of DFID in Central Asian countries, see <http://www.dfid.gov.uk/countries/allcountries.asp?view = region $>$; for GTZ's activities in Central Asia and Caucasus, see < http://www.gtz.de/en/weltweit/ europa-kaukasus-zentralasien/kasachstan/4216.htm > ; for UNDP activities in Europe and CIS, see < http://www.undp.org/europe/ > ; for the assistance to Central Asia, see < http://web.worldbank. org/WBSITE/EXTERNAL/COUNTRIES/0,,pagePK:180619 theSitePK:136917,00.html> ; for EBRD's aid to Central Asia region see <http://www.ebrd.org/country/index.htm $>$.

${ }^{55}<$ http://www.usaid.gov/policy/budget/cbj2006/ee/kz.html > ; <http://www.dfid.gov.uk/ countries/asia/Kazakhstan.asp $>$.
} 
1992 and 2001. ${ }^{53}$ Unfortunately, all these activities were completed in an uncoordinated manner and almost all of them were demand-driven rather than result-oriented activities. Therefore, there had been cases of duplication which led to the waste of time and resources and failed to reach the objectives of aid effectiveness.

Due to these handicaps, Turkey's foreign assistance to the Eurasian region failed to sustain its initial intensity whereas other bilateral and multilateral aid agencies such as USAID, DFID, GTZ, UNDP, World Bank and EBRD (European Bank for Reconstruction and Development) in the same period got more and more involved in terms of technical cooperation in Eurasian countries both in quantity and quality. ${ }^{54}$

When examining their performance by country level, one can be easily impressed by the huge amounts of other bilateral donors' assistance, for instance, USAID has spent \$26 million for Kazakhstan in 2006, while DFID has spent over $£ 17$ million on development assistance for Kazakhstan since $1992 .^{55}$ TIKA's $^{\prime}$ contribution to Kazakhstan has amounted to \$31.6 million by the end of 2006 . However, $\$ 17.5$ million out of it was spent for the restoration projects; the real amount spent for priority areas was less impressive given Turkey's geographical proximity and historical links with Central Asia.

When the priority areas are concerned, it is noted that USAID has many success stories in the fields of health, education, rule of law and business development. While DFID's key achievements in Kazakhstan include the areas of sustainable land use, primary health care, water resources management and poverty reduction, GTZ's aid in Kazakhstan concentrates on the priority areas such as promoting economic development institutions in selected regions, reform of vocational and technical education and legal and judicial reform. Since its inception in 1992, TIKA's ODA efforts towards its partner countries has focused on capacity-building activities on agricultural and livestock, improvement of physical infrastructure, social development for raising living standards, vocational training programmes and employment-promotion activities, conservation of common cultural and historical heritages, and cultural programmes. From the elaboration above, it can be easily seen that USAID, DFID, GTZ and TIKA do have something in common in terms of priority areas. As there are some overlapping areas among these donors, active aid coordination would not only save their time and resources, but also help them channel additional resources to other areas of need in partner countries.

In order to regain the intensity of aid activities in the region, it was necessary for TIKA to avoid duplication and the cases of lack of coordination between other Turkish institutions. At the domestic level, TIKA is now in a position to assume the responsibility to coordinate aid flows. For this end, TIKA has been signing cooperation protocols with different public institutions of Turkey to tap the humanitarian and instrumental resources of sister institutions for the well-being of partner countries. As for the international dimension of development cooperation, there are examples of good practice of TIKA's cooperation with the

\footnotetext{
${ }^{56}$ TIKA 2004 Y1l Faaliyet Raporu, <http://www.tika.gov.tr> .

${ }^{57}<$ http://www.mofa.go.jp/policy/oda/mid-term/1999/methods.html> .

${ }^{58}$ For further elaboration on the importance of aid coordination, see OECD DAC Report 1985: Twenty-Five Years of Development Cooperation-A Review, OECD, Paris, 1985, pp. 195-197.
} 
other development cooperation agencies. For instance, the cooperation has been based on the pattern of 'request for project support' (GTZ's support to OECD Istanbul Centre for Private Sector Development until 2000), 'sectoral and geographic partnership' (TIKA-UNDP Crimean Integration Project) ${ }^{56}$ and 'agency to agency agreement to create a trust fund' (trust fund agreement between TIKA and World Bank Institute for capacity-building activities). Negotiations have also been going on to increase cooperation with International Trade Centre (ITC), UNIDO and a number of other agencies. When cooperating with other ODA agencies, it is very important to explore the fields where these agencies are especially experienced and enjoy comparative advantages; at the same time, it is also crucial to promote cooperation through collaboration and exchange of information with aid agencies. ${ }^{57}$

It is well understood that successful aid coordination requires donors working together to make the most of their respective strengths and to provide more efficient aid. ${ }^{58}$ TIKA believes that only through cooperation with other aid agencies will aid effectiveness and aid harmonization be a reality. ${ }^{59}$ Nonexistence of effective coordination could always result in duplication of projects. In recent years, the DAC of OECD stressed the importance of aid effectiveness and harmonization among the donors on several occasions. ${ }^{60}$ From TIKA's experience, OECD Istanbul Private Sector Development Centre is a good example for multilateral cooperation between the donors, as in its initial stage; the parties involved include TIKA, OECD and GTZ.

TIKA is working in this direction and has numerous experiences in aid coordination with international organizations and bilateral donors. Just to name a few, the Crimea Integration and Development Program, launched by UNDP in 1995 at the request of the Government of Ukraine, is a very good example for aid coordination among donors. From 1998 onwards, TIKA has contributed $\$ 2$ million to the programme and dispatched experts to take part in it upon request, and ranks second after CIDA (Canada) among the donors. SDC (Switzerland), SIDA (Sweden), the UK, Greece, Norway and MATRA (the Netherlands) are the other donors. ${ }^{61}$

With the establishment of Turkey/World Bank Institute (WBI) Partnership Program in 1997, TIKA enjoys a cooperation relationship with the WBI in extending training, learning and knowledge-sharing activities to the Eurasian countries. The period between 1998 and 2003 witnessed the TIKA/WBI collaboration in training participants from partner countries by organizing seminars in the fields of Banking Reform, Securities Market Development and Reform, Global Integration and the New Trade Agenda, etc. Turkey/WBI Partnership Program not only promoted partner countries' economic and social development, but also avoided duplication in this regard.

As mentioned above, at the Donors Conference held in Brussels on 16-17 June 2004, ${ }^{62}$ Turkey stated its position in support of the new Government of

\footnotetext{
${ }^{59}$ For an account of the principle of aid harmonization, see DAC Guidelines and Reference Series, Managing Aid: Practices of DAC Member Countries, OECD, 2005, p. 17.

${ }^{60}$ DAC Guidelines and Reference Series, Harmonizing Donor Practices for Effective Aid Delivery, pp. 17-27; The DAC Journal, Development Cooperation 2003 Report, Vol. 5, No. 1; The DAC Journal, Vol. 4, No.3.

${ }^{61}<$ http://www.undp.crimea.ua/eng/>

${ }^{62}<$ http://www.seerecon.org/georgia/index.html $>$.
} 
Georgia. Moreover, TIKA made it clear its intention to act as a proxy or partner in the implementation of projects in Georgia if other donor countries and agencies needed it as a result of lack of delivery mechanisms in the country. TIKA also stressed its determination to put together a coherent programme taking into account the needs of Georgia as well as pledging a sum of $\$ 5$ million for bilateral projects there in a five-year period.

The meeting organized by the European Commission and the World Bank provided an opportunity for participants to discuss the main priorities and the agenda for further elaboration of Georgia's Economic Development and Poverty Reduction Program (EDPRP) and full public investment programme, which was a good example of donor cooperation. It is widely believed that the support of the international donor community to Georgia would certainly help her establishing an appropriate investment climate as well as restructuring and reviving the economy.

TIKA has strengthened its friendly relations with other donor countries and agencies through the above-mentioned aid coordination activities. In addition to increasing cooperation relationship with other aid agencies, TIKA has seconded its staff to OECD and UNDP regional offices in Bratislava on a six-month basis, and looks forward to expanding such cooperation with other multilateral aid agencies, such as UNIDO. Since the inception of this programme, the seconded staff have not only familiarized themselves with the organizational structure and work of the receiving agency, but have also contributed a great deal to the activities of the receiving agency.

\section{Concluding remarks}

The period between the late 1940s and early 1990s has witnessed Turkey's evolution from an aid recipient country to a donor country. With the establishment of TIKA in 1992, Turkey's foreign assistance endeavours which were initiated in the mid-1980s gained momentum. However, due to lack of effective coordination among domestic institutions, Turkey was neither able to sustain its aid capacity nor to catch up with other bilateral donors in its priority areas. However, given its flexible organizational and budgetary structure, TIKA maintained its friendly relations with many bilateral and multilateral aid agencies through designing and implementing joint projects.

The collapse of the cold war order, as well as the worsening economic conditions in developed nations, has resulted in the decrease of aid to developing countries. This kind of global change has made aid coordination and aid harmonization a necessity among donors with reasonably limited resources. TIKA is well aware of this change and takes a different approach than 10 years ago to Central Asia, Africa, the Balkans, Black Sea and the Caucasus regions for the purpose of effective use of its aid budget.

A key challenge facing TIKA is now how to become an effective aid agency, in comparison to the other donors like GTZ, JICA, DFID and USAID, etc.

\footnotetext{
${ }^{63} 2005$ Development Co-operation Report, OECD DCD/DAC(2005)59/REV1, pp. 93-94; The DAC Journal Development Co-operation Report 2004 (2005, Vol. 6, No. 1).
} 
To strengthen internal coordination in the area of development aid among the Turkish governmental institutions, the Turkish Prime Ministry released a decree on 21 April 2005 to declare officially TIKA as the single government institution charged with the task of coordinating ODA and taking over the task of ODA data collection from the Turkish Statistics Institute to meet the OECD DAC standard of development cooperation. After these structural changes, past handicaps of underreporting of ODA figures due to insufficient internal coordination have been rapidly overcome, and ODA figures for 2004 from various Turkish public institutions have started to pour into TIKA statistics database ever since. Thus, Turkish ODA rose tremendously from $\$ 66.63$ million in 2003 to $\$ 339.15$ million in 2004 , representing 0.12 per cent of GNI. ${ }^{63}$ In 2005, Turkish ODA totalled $\$ 601.04$ million, representing 0.17 per cent of GNI, rising by $\$ 262$ million in comparison with 2004.

Although Turkey's development assistance was kicked off in 1985, since 1997, the ODA Turkey has disbursed has exceeded the ODA it has received according to the average level despite some setbacks due to the economic crisis in 2001. Therefore, Turkey can be considered as a major emerging donor country and on the way to fulfilling the requirements set out by the OECD DAC to be eligible for full membership. ${ }^{64}$

In keeping up with the new trends of ODA, TIKA is in active dialogue with DAC donors and non-DAC donors. For instance, TIKA is at the stage of concluding cooperation agreements with UNIDO, FAO and IFAD, and is exploring areas of cooperation with the Islamic Development Bank and ITC as well.

The entry of new donors into the development cooperation arena will bring additional resources, opportunities and fresh perspectives. TIKA has already brought new resources, opportunities and fresh perspectives to this area. Based on its decade of experience on development cooperation, TIKA is set to take a prominent place among the emerging donors.

Hakan Fidan was appointed as the Head of Turkish International Cooperation and Development Agency (TIKA) on 22 December 2003. His research interests include Turkish foreign policy, strategy, information revolution, and international security and development. Mr Fidan has received, among others, the award of The Bureaucrat of the Year 2005 (First Business Magazine). He holds a PhD International Relations from Bilkent University in Ankara.

Rahman Nurdun received his MA in Area Studies from the School of Oriental and African Studies of University of London (1994-1995), and his PhD from Hacettepe University, Ankara in 2002. He is now working as a Senior Expert in Turkish International Cooperation and Development Agency.

Address for correspondence: TIKA, Ataturk Bulvari No. 15, Opera Meydani, Ulus/Ankara, Turkey. E-mail: Rahman@tika.gov.tr

\footnotetext{
${ }^{64}$ As Turkey is paying back loans of the IMF, which are not counted as ODA, Turkey can be considered as a net donor within this context.
} 